\title{
Urea Metabolism and Recycling in Ruminants
}

\author{
Daniel Getahun1, Tewodros Alemneh², Dawit Akeberegn ${ }^{3}$, Mebrate Getabalew $^{1}$ and Derebie Zewdie ${ }^{1}$ \\ ${ }^{1}$ Department of Animal Science, College of Agricultural and Natural Resource Science, Debre Berhan University, Ethiopia \\ ${ }^{2}$ Woreta City Office of Agriculture and Environmental Protection, South Gondar Zone, Amhara Regional State, Ethiopia
}

${ }^{3}$ Debre Berhan City Municipality Office, Meat Inspection \& Hygiene, Semen Shewa Zone, Amhara Regional State, Ethiopia

*Corresponding author: Tewodros Alemneh, Woreta City Office of Agriculture, Ethiopia

\section{ARTICLE INFO}

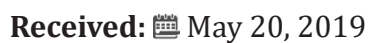

Published: 慧 July 29, 2019

Citation: Getahun D, Alemneh T, Akeberegn D, Getabalew M, Zewdie D. Urea Metabolism and Recycling in Ruminants. Biomed J Sci \& Tech Res 20(1)2019. BJSTR. MS.ID.003401.

Abbreviations: AA: Amino Acids; MCP; Microbial Crude Proteins; GIT: Gastrointestinal Tract; RFC: Ruminally Fermentable Carbohydrate; VFA: Volatile Fatty Acids; IIP : Indigestible Intake Protein; AHA: Acetohydroxamic Acid; PPD: Phosphoric Phenyl Ester Diamide; NBPT: N(n-butyl) Thiophosphoric Triamide

\section{ABSTRACT}

The major sources of nitrogen $\left(\mathrm{N}_{2}\right)$ in the diet of mammals are amino acids and peptides derived from ingested proteins. The immediate end product of mammalian protein catabolism is ammonia, which is toxic to cells if allowed to accumulate. Therefore, amino acids are broken down in the liver into urea, which is used as non-protein nitrogen in the rations of ruminants as an economical replacement for feed proteins. Urea transferred from the blood to the rumen is also an important source of nitrogen for rumen microbial growth. Mammals cannot break down urea, which is traditionally viewed as a simple waste product passed out in the urine. However, urea from the bloodstream can pass into the gastrointestinal tract, where bacteria expressing urease cleave urea into ammonia and carbon dioxide. The bacteria utilize the ammonia as a nitrogen source, producing amino acids and peptides necessary for growth. Interestingly, these microbial products can be reabsorbed back into the host mammalian circulation and used for synthetic processes; because of this reason, urea has commonly become an accepted ingredient in the diets of ruminants. Therefore, this review focuses on urea metabolism and recycling in ruminants.

Keywords: Urea; Metabolism; Ammonia; Urea $\mathrm{N}_{2}$; Urea Recycling; Ruminants

\section{Introduction}

Urea and ammonia, in addition to amino acids (AA), peptides and microbial crude proteins (MCP), play an important role in nitrogen digestion and metabolism in ruminants. Also, urea could be used to replace a portion of dietary protein in ruminants [1]. Thereafter, some studies were conducted on the use of NPN in ruminant diets. During the 1970s and 1980s, multiple studies were conducted on the utilization of urea as a replacement for protein in ruminant diets, especially its effect on dry matter intake [2], rumen fermentation [1,3] milk yield and reproduction-related parameters $[4,5]$. Ruminants can utilize non protein nitrogen as a dietary protein source via their rumen microorganisms [6].

In most mammalian species, a large amount of endogenous urea- $\mathrm{N}$ is excreted via the urine. However, ruminants have evolved a mechanism that allows constant recycling of urea- $\mathrm{N}$ to the gastrointestinal tract (GIT), particularly to the rumen, where urea- $\mathrm{N}$ can be used as a source of $\mathrm{N}$ for microbial protein, which is the major contributor to the metabolizable protein supply to the small intestine. Urea-N recycling to the GIT and its utilization for anabolic use is influenced by several dietary and ruminal factors. Major dietary factors which regulate the proportion of hepatic urea output returning to the GIT and its subsequent fate are: dietary $\mathrm{N}$ concentration and $\mathrm{N}$ intake $[7,8]$; total dry matter intake [9]; feed processing [10-12]; oscillating dietary $\mathrm{N}$ levels [13] and amount as well as frequency of feeding dietary $\mathrm{N}$ that is degraded in the rumen $[14,15]$. In juxtaposition with dietary factors, ruminal factors such as ruminal NH3-N concentration, ruminal bacterial urease activity, ruminally-fermentable carbohydrate (RFC), ruminal concentrations of volatile fatty acids (VFA) and $\mathrm{CO}_{2}$, and ruminal $\mathrm{P}^{\mathrm{H}}$ also play a significant role in trans-epithelial movement of blood urea-N into the rumen [10]. So, the objective of this review is to assess the metabolism and recycling of urea in the ruminants. 


\section{Literature Review}

\section{Ammonia Production and Ammonia Toxicity}

Usually, ruminants are much less efficient than no ruminants in utilizing high quality dietary proteins. A dominant feature of $\mathrm{N}$ Digestion and metabolism is microbial conversion of some dietary protein to $\mathrm{NH}_{3}$. In ruminants, ammonia is generated by amino acids obtained from the diet, from catabolism of glutamine by enterocytes, or from peripheral tissues such as skeletal muscle. In mammals, at least 20 metabolic reactions generate ammonia, with the glutaminase, glutamate dehydrogenase and purine nucleo-tide cycle pathways producing most of the ammonia [16]. Ammonia generation in the gut results from two main processes: one is microbial degradation of nitrogenous compounds within the gut lumen; the other is microbial hydrolysis of urea passing across the gut wall from the blood and intestinal fluids [3].

The primary source of $\mathrm{NH}_{3}$ within the rumen is dietary protein, except for ruminants consuming diets very low in protein. The UIP and indigestible intake protein (IIP) usually pass to the duodenum without affecting $\mathrm{NH}_{3}$ production in the rumen. Degradable dietary NPN can be converted rapidly and quantitatively to $\mathrm{NH}_{3}$ dissolved nucleic acids in the rumen are also degraded extensively by rapid action of bacterial peptidases and deaminases to produce $\mathrm{NH}_{3}$ [17] Much of the daily ammonia load is derived from the catabolism of amino acid obtained from dietary proteins. In animals with high protein intake, $10 \%$ to $15 \%$ of the protein is delaminated and used for energy, with resultant ammonia production [18]. Urea recycling is significantly related to $\mathrm{NH}_{3}$ production and absorption in the gastrointestinal tract (GIT) of ruminants. All NH3 absorbed from the rumen epithelium, small intestinal mucosa, and large intestinal mucosa travels via the portal vein to the liver; body tissue $\mathrm{NH}_{3}$ also en- ters the liver. Liver metabolism has a central role in the integration of body $\mathrm{N}$ metabolism. Ammonia in the liver is detoxified by conversion to urea, urea can then is recycled directly into the rumen, small intestine, or large intestine; it can enter the rumen in saliva, be excreted by the kidney, or be secreted in milk or sweat [19].

\section{Metabolism of Urea in the Liver}

Under normal physiological and nutritional conditions, $\mathrm{NH}_{3}$ absorbed into the portal vein is efficiently extracted by the liver and detoxified by conversion to urea or glutamine. Over a wide range of portal NH3 concentrations and on a variety of diets, the liver is able to extract 70 to $95 \%$ of portal NH3. As a result, hepatic $\mathrm{NH}_{3}$ removal is on average slightly higher (4\%) than portal absorption [17]. The structure and function of the liver attests to the importance of removing potentially toxic $\mathrm{NH}_{3}$ from blood of ruminants as well as other mammals. The enzymes of the ornithine cycle and enzymes catalyzing transamination reactions are structurally oriented in mitochondria and cytosol of per portal and per venous hepatic cells to form urea from $\mathrm{NH}_{3}$ absorbed from the gut and to use glutamine synthesis as another pathway to remove essentially all $\mathrm{NH}_{3}$ from hepatic portal blood (Figure 1). Per portal cells remove $\mathrm{NH}_{3}$ from hepatic portal blood and use their enzymatic machinery to synthesize urea. The specialty of the perivenous cells is production of glutamine through glutamine syntheses, thereby providing another opportunity to remove $\mathrm{NH}_{3}$ from circulation before blood enters the hepatic veins and subsequently general circulation. This two-stage $\mathrm{NH}_{3}$ removal system integrates with other systems, including gluconeogenesis, regulation of acid-base balance, and interorgan $\mathrm{N}$ shuttles to derive the best metabolic control of substrate and product balances, nutrient supplies, and nutrient needs of the organism [20].

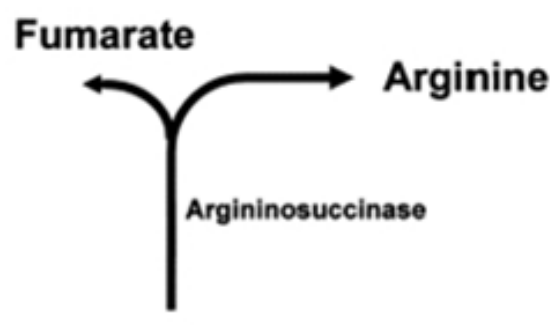

Argininosuccinate

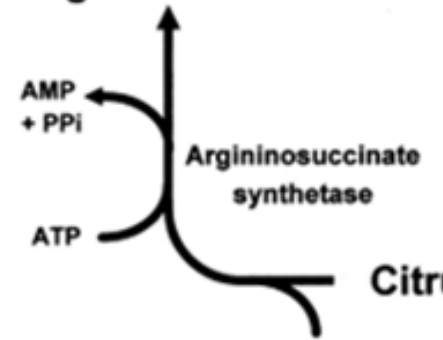

Aspartate
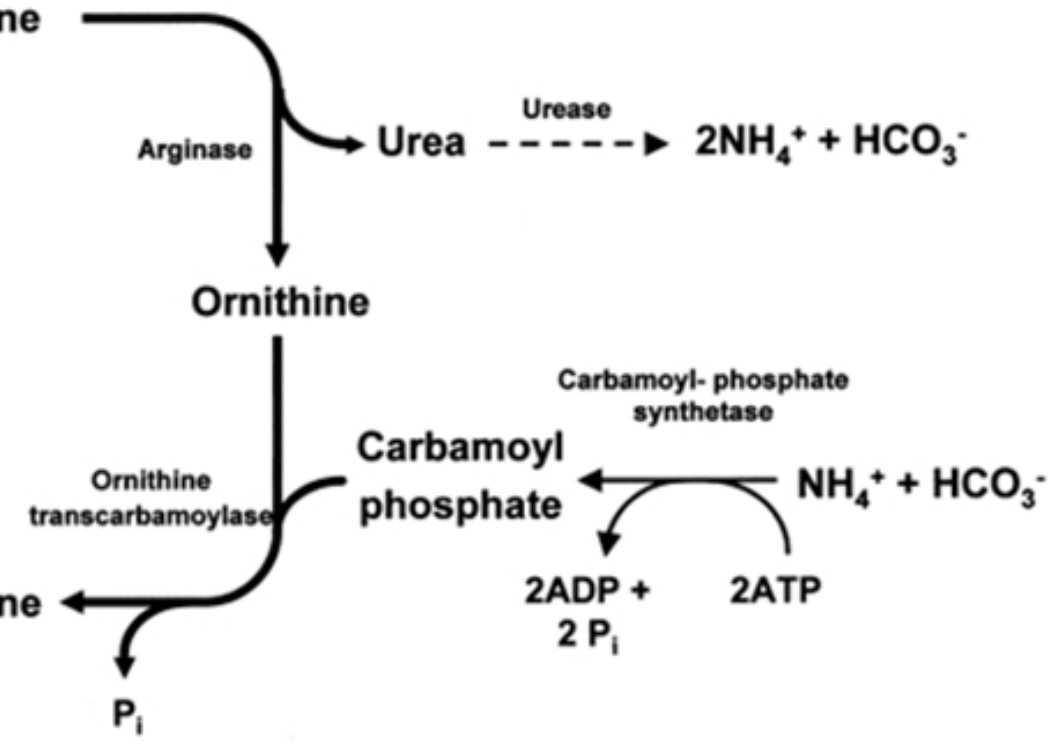

Figure 1: Urea Cycle in the Liver of Ruminants [21]. 


\section{Rumen Ureolytic Bacteria}

Rumen ureolytic bacteria play an important role in dietary urea hydrolysis, for they produce ureases that catalyze the breakdown of urea to ammonia $\left(\mathrm{NH}_{3}\right)$ and carbon dioxide [21, 22]. In the rumen, the ammonia can be assimilated by many rumen bacteria for the synthesis of microbial proteins [22]. However, the efficiency of urea $\mathrm{N}$ utilization in ruminants is low and this is attributed to the rapid hydrolysis of urea to $\mathrm{NH} 3$, which occurs at a higher rate than $\mathrm{NH}_{3}$ utilization by rumen bacteria [23]. Due to the difficulty in cultivating rumen bacteria, only a small number of bacteria have been isolated [24]. The lack of sufficient understanding of the ruminal microbiome is one of the major knowledge gaps that hinder effective enhancement of rumen functions [25]. In addition, limited information about rumen urea-degrading bacteria makes regulation of the urea hydrolysis rate by targeting predominant ureolytic bacteria difficult.

\section{Urea Transport}

Urea transport Across the Rumen Epithelium: Urea produced in the liver is transferred across the rumen wall from the blood and then it is hydrolyzed to ammonia by resident bacteria [26]. As is already known, urea transport across the ruminant wall is mediated via urea transporters in the epithelium membrane [27]. These transporters allow the passage of urea across cell membranes, down a concentration gradient [28]. Facilitative urea transporters are derived from the UT-A and UT-B genes [29]. UT-B mRNA or protein expressions have been characterized in the rumen epithelium [30]. In the study of Coyle et al. [31], UT-B transporters were identified to be specifically localized to certain regions of tissue in the bovine gastrointestinal tract. Hepatic urea-N synthesis has two fates i.e., it is either excreted in the urine or is recycled back to the GIT via salivary secretions or by the direct transfer across the epithelial tissues of the digestive tract [32]. All mammalian species have the mechanism of urea-N recycling to the GIT. However, in ruminants the amount of urea-N recycled to the GIT (as a proportion of total hepatic urea-N output) varies between 29 to $99 \%$, which is much greater compared to non-ruminants (15 to 39\%) [33]. Animals utilize the released urea- $\mathrm{N}$ in a number of ways. In sheep, $30-50 \%$ of the urea that enters the digestive tract is returned to the host as ammonia, whereas this value is $25-40 \%$ for cattle [26]. The ammonia produced by urea hydrolysis is directly reabsorbed passively, independent of ionic concentrations, from both the rumen and the post-ruminal gut, particularly the caecum and large intestine. Approximately $20 \%$ of ruminal ammonia flux in sheep is derived from urea- $\mathrm{N}$ rather than ingested $\mathrm{N}$ [34].

Urea-N Recycling to the GIT: After synthesis, urea-N may either enter the gastrointestinal tract (GIT) or be excreted in the urine via the kidneys [5]. Urea- $\mathrm{N}$ that enters the rumen is able to be utilized by the microbial population and thereby improve whole animal $\mathrm{N}$ utilization. The quantity of urea- $\mathrm{N}$ that enters the GIT (GER) varies widely across and among species. Values of GER: N intake ranged from 0.19 to 0.80 among species and physiological status, with no apparent patterns observed among them (Figure 2). Urea-N recycling to the GIT occurs in all mammals; however, the magnitude of urea-N recycling is much greater in ruminants. Data from a variety of studies indicate that hepatic urea-N synthesis may be as high as digestible $\mathrm{N}$ intake (33 to 99\%) and often exceeds digestible $\mathrm{N}$ intake [33]. Urea enters the ruminant gut by several routes. Although urea secreted in saliva accounts for between 10 and $40 \%$ of ruminal urea entry, the majority of urea enters across the gastrointestinal tract wall particularly across the ruminal epithelium. There is also a minor inflow in the bile secretion and pancreatic juice [35].

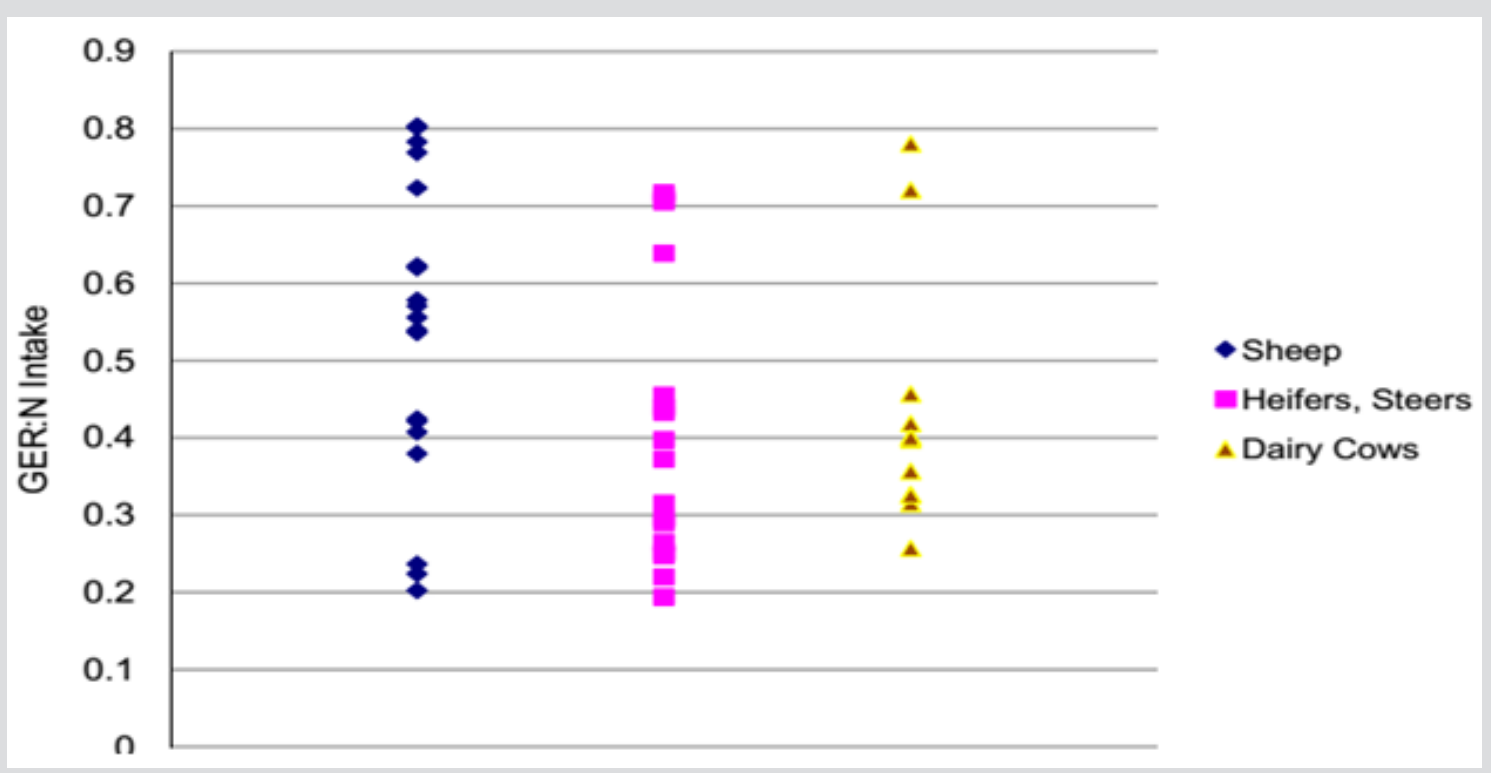

Figure 2: Gastrointestinal urea-N entry rate (GER) as a proportion of $\mathrm{N}$ intake in sheep and cattle studies [33]. 
However, the relative contributions of these routes can vary enormously depending on a complex interaction of factors, including the composition of diet ingested. For example, in cattle fed a concentrate diet, saliva secretion accounted for $17 \%$ of the total gut entry of urea, whereas in cattle fed a forage diet this value increased to $36 \%$ [26]. In high and rapidly growing ruminants, urea-N recycling to the GIT is so important that it can increase the $\mathrm{N}$ availability to the GIT from 43 to $130 \%$ [26]. Total urea synthesis in the liver can be as high as 33 to $99 \%$ of $\mathrm{N}$ intake. Of that total endogenous hepatic urea-N production in the liver, 1 to $71 \%$ of urea- $\mathrm{N}$ is excreted in the urine and about 29 to $99 \%$ enters the GIT. In the GIT 16 to $70 \%$ of urea-N (as a proportion that enters the GIT) is utilized for anabolic purposes and 3 to $21 \%$ is lost in feces. Unutilized urea-N (i.e., NH3-N) is returned to the ornithine cycle (17 to $80 \%$ of urea-N that enters GIT) for urea synthesis. The data depicted in this figure are obtained from urea-N kinetic measurements obtained from intra-jugular infusion of $15 \mathrm{~N} 15 \mathrm{~N}$-urea [36].

Urea Entry into the Rumen: Available data from literature $[10,34]$ shows that between 27 to $60 \%$ (combined salivary contributions and transfer across the rumen wall) of the GIT entry is to the rumen. The quantity of urea-N transfer to different sections of the GIT is regulated by characteristics of the ruminant diet. Huntington [11] demonstrated that in steers fed high concentrate diets, up to $95 \%$ of urea- $\mathrm{N}$ (as a proportion of urea-N entry to the GIT) enters the rumen, as compared to $62.5 \%$ in steers fed high forage diet. Urea- $\mathrm{N}$ can enter the rumen via direct transfer of blood urea-N across the ruminal wall or via salivary secretions. Salivary urea- $\mathrm{N}$ entry to the rumen calculated as difference between total splanchnic flux and urinary excretions rate as a percent of total hepatic urea- $\mathrm{N}$ production represented $72 \%$ in steers fed high forage diets as compared to $21 \%$ in those fed high concentrate diet [11]. High roughage diets stimulate rumination, thus increasing the flow of salivary secretions to the rumen. Reports from other studies also show that salivary flow of urea-N into the rumen as a percent of total urea-N entry to the GIT was 36\% in forage-fed [17] and $16 \%$ in concentrate-fed [37] ruminants. Recently, Ludden et al. [38] showed that UT-B proteins are present in the parotid gland in sheep and may be involved in the facilitated carrier-mediated transfer of urea-N into the saliva.

Urea Entry into the Small and Large Intestine: In ruminants, up to $70 \%$ of the total portal-drained viscera flux of urea can enter post-stomach (small intestine) compartments [26] of which up to $90 \%$ of total portal-drained viscera flux of urea is to the mesentericdrained viscera in animals fed high fiber diets [11] as compared to only $19 \%$ in animals fed high concentrate diets [32]. However, most of the urea- $\mathrm{N}$ that enters post-stomach compartments is returned back to the ornithine cycle as NH3 for re-synthesis of urea [26]. Small amounts of urea-N are recycled to the hind gut (cecum and colon) and, even though bacteria residing in the hind gut utilize recycled urea-N for protein synthesis, because there are no mechanisms for digestion and absorption of microbial protein formed in the hind gut, it is eventually lost in the feces [33].

\section{Factors Affecting Urea Recycling}

All factors that influence the production, absorption, and transfer of $\mathrm{NH}_{3}$ and urea will affect urea recycling in ruminants. Kennedy and Milligan [10] reported that urea transfer to the rumen was inversely related to the rumen $\mathrm{NH}_{3}$ concentration and suggested that the $\mathrm{NH} 3$ concentration was a factor regulating urea entry into the rumen. There was a marked reduction of urea transfer to the rumen when the ruminal $\mathrm{NH}_{3}$ concentration was elevated by continuous $\mathrm{NH}_{3}$ infusion into it. Tracer studies have indicated that a supplemental energy source such as grain, starch, or dried beet pulp, significantly increased endogenous urea degradation in the gastrointestinal tract. It is possible that the rumen was the site of increased degradation because Kennedy and Milligan, [10] reported that dietary sucrose greatly enhanced the rate of transfer of urea to the rumen. On the other hand, urea transfer from blood to the GIT might not be controlled by the urea concentration in plasma alone. In sheep and cattle, the upper limits of the blood urea concentration above which urea transfer was no longer linearly related to plasma urea concentrations were $6.0 \mathrm{~mm}$ and $4.0 \mathrm{~mm}$, respectively. Elevation of plasma urea above these concentrations did not further increase rumen $\mathrm{NH}_{3}$. Norton et al. [39] found that transfer of urea into the post-ruminal tract is correlated with both plasma urea concentration and its production rate.

Inhibition: Increasing intraruminal ammonia concentration decreases the urea flux across the rumen wall [40]. According to Remond et al. [41], ammonia absorption may be responsible for reducing urea flux. The effect of ammonia on urease activity is long term [42] rather than short term, and the mechanism by which ammonia regulates the trans-epithelial flux of urea during shortterm variations is not yet known.

Impact of Animal Factors on Urea Recycling: Production of urea is largely a substrate-driven process. Thus, animal productivity can impact urea recycling by impacting how much $\mathrm{N}$ is available for urea synthesis. When cattle use more $\mathrm{N}$ for productive purposes (i.e., growth or lactation), less $\mathrm{N}$ are available for urea synthesis and therefore less urea are recycled to the gut. Bailey [43] compared urea recycling in forage-fed steers weighing 208 and $391 \mathrm{~kg}$; the larger steers were physiologically more mature and deposited less $\mathrm{N}$ in tissue proteins than the younger steers. The more mature cattle had greater urea synthesis and greater urea recycling than the younger cattle that deposited more tissue protein. Thus, body protein utilization impacts urea recycling.

Urease Inhibitors in Ruminants: Urea hydrolysis to ammonia in the rumen is very rapid, which can override its utilization by the ruminal microorganisms and lead to ammonia toxicity and wastage of nitrogen of feeds. Therefore, slowing down the urea hydrolysis may reduce ammonia loss and improve urea utilization. Coated urea or slow release urea products as protein supplements could constantly supply ammonia to ruminal microorganisms for their growth without the potential toxicity associated with feedgrade urea [44], which may also improve nutrient utilization for 
low-quality forages and reduce plasma ammonia concentrations [45]. Another strategy, which has been explored for many years to decrease the urease activity in the rumen, is the use of urease inhibitors (Table 1). A number of urease inhibitors such as acetohydroxamic acid (AHA), phosphoric phenyl ester diamide
(PPD), N- (n-butyl) thiophosphoric triamide (NBPT), boric acid, bismuth compounds and hydroquinone decrease ureolytic activity. However, some of these compounds pose potential risks to animal and human health, thus precluding their use in production. These inhibitors usually work very well when tested in vitro [46-49].

Table 1: Different urease inhibitors used to inhibit ureolytic bacteria and urease activity in the gastrointestinal tract of livestock animals.

\begin{tabular}{|c|c|c|c|}
\hline Urease Inhibitor & System & Response & Reference \\
\hline $\begin{array}{c}\text { Phenylphosphoryldiamidate }(1 \mathrm{~g} / \text { day }) \text { infusion } \\
\text { into the rumen }\end{array}$ & Sheep & $\begin{array}{l}\text { a) Reduced urease activity by }>98 \% \text {, rumen ammonia concentration } \\
\text { by } 40 \% \text {, urea degradation by } 70 \% \text {. } \\
\text { b) Increased in plasma urea concentration and nitrogen retention. } \\
\text { c) No effect on urea excretion }\end{array}$ & [6] \\
\hline $\begin{array}{c}\text { Phenylphosphoryldiamidate }(1 \mathrm{~g} / \text { day }) \text { infusion } \\
\text { into the abomasum }\end{array}$ & Sheep & $\begin{array}{l}\text { a) Decreased urease activity by } 40 \% \\
\text { b) No effect on urea metabolism. }\end{array}$ & [6] \\
\hline $\begin{array}{l}\mathrm{N} \text { (n-butyl) thiophosphoric triamide }(0.125-4 \mathrm{~g} / \\
\text { day) }\end{array}$ & Sheep & $\begin{array}{l}\text { a) Decreased ruminal urease activity and ammonia linearly and } \\
\text { increased ruminal urea linearly } \\
\text { b) Inhibitor activity reduced with day } \\
\text { c) No effect on dry matter or fiber digestibility, but nitrogen } \\
\text { digestibility. } \\
\text { d) Increased urinary nitrogen excretion and decreased nitrogen } \\
\text { retention linearly }\end{array}$ & [38] \\
\hline Vaccination, UreC proteins of H. pylori & Cow & $\begin{array}{l}\text { a) Decreased urease activity in rumen fluid by } 17 \% \text {. } \\
\text { b) Lowered ureolysis and ammonia concentration in the ruminal } \\
\text { fluid. }\end{array}$ & [47] \\
\hline Vaccination, jack bean urease & Calves & a) Increased growth rate and feed efficiency & [48] \\
\hline
\end{tabular}

\section{Conclusion}

Urea is one of the major non-protein nitrogen feeds for ruminants and the optimal utilization of urea in feed can alleviate to some extent the cost of dietary protein. Urea is hydrolyzed quickly by ureolytic bacteria in the rumen. The ability of the liver to detoxify NH3 to urea appears to be similar in ruminant and nonruminant species, the principal difference being that the production of $\mathrm{NH}_{3}$ by foregut fermentation in ruminants is extremely variable and dependent on feed sources, whilst in non-ruminants, $\mathrm{NH}_{3}$ is produced in the hindgut and, therefore, absorption into the portal vein is affected far less by diurnal feed cycles. Despite the high rates of uptake from the gut, which result from rapid fermentation of soluble $\mathrm{N}$ in forage diets, the ruminant liver is extremely adept at detoxifying $\mathrm{NH}_{3}$ to urea. However, there is evidence to suggest that $\mathrm{NH}_{3}$ detoxification to urea imposes a metabolic 'cost' in terms of amino acid deamination. This could explain observations of poor $\mathrm{N}$ retention in forage-fed ruminants, although further specific metabolic studies are required to identify mechanism which could explain this interaction of $\mathrm{NH}_{3}$ with amino acid metabolism. Also urea that is produced in the rumen is circulating in to gastro intestinal tract of ruminants.

\section{Acknowledgment}

Authors would like to thank Debre Berhan University Librarians, Staffs and the Community in general for their logistic and material supports that greatly aid for the success of this work.

\section{Conflict of Interest}

Authors declare that no conflicting of interests.

\section{References}

1. Kertz A, Devidson L, cordes B (1983) Ruminal infusion of ammonium chloride in lactating cows to determine effect of $\mathrm{pH}$ on ammonia trapping. J Dairy Sci 66(12): 2597-2601.

2. Wilson G, Martz F, Campbell J, Becker B (1975) Evaluation of factors responsible for reduced voluntary intake of urea diets for ruminants. J Anim Sci 41(5): 1431-1437.

3. Pisule Ski PM, O korie AU, Buttery PJ, Haresign W, Lewis D (1981) Ammonia concentration and protein synthesis in the rumen. J Sci Food Agric 32(8): 759-766.

4. Ryder W, Hill Man D, Huber J (1972) Effect of feeding urea on reproductive efficiency in Michigan Dairy Herd Improvement Association herds. J Dairy Sci 55(9): 1290-1294.

5. Erb R, Brown C, Callahan C, Miller N, Hill D, et al. (1976) Dietary urea for dairy cattle. II. Effect on functional traits. J Dairy Sci 59(4): 656-667.

6. Whitelaw FG, Milnde JS, Wright SA (1991) Urease (EC 3.5.1.5) inhibition in the sheep rumen and its effect on urea and nitrogen metabolism. Br J Nutr 66(2) : 209-225.

7. Bunting LD, JA Boling, CT Mackown, RB Muntifering (1987) Effect of dietary protein level on nitrogen metabolism in lambs: studies using 15N-nitrogen. J Anim Sci 64(3): 855-867.

8. Marini JC, JM Klein, JM Sands, ME Van Amburgh (2004) Effect of nitrogen intake on nitrogen recycling and urea transporter abundance in lambs. J Anim Sci 82(4): 1157-1164.

9. Sarraseca A, Milne E, Metcalf MJ, Lobley GE (1998) Urea recycling in sheep: Effects of intake. Br J Nutr 79(1): 79-88. 
10. Kennedy PM, Milligan LP (1980) The degradation and utilization of endogenous urea in the gastrointestinal tract of ruminants: a review. Can J Anim Sci 60(2): 205-221.

11. Huntington GB (1989) Hepatic urea synthesis and site and rate of urea removal from blood of beef steers fed alfalfa hay or a high concentrate diet. Can J Anim Sci 69(1): 215-223.

12. Theurer CB, GB Huntington, JT Huber, RS Swingle, JA Moore (2002) Net absorption and utilization of nitrogenous compounds across ruminal, intestinal, and hepatic tissues of growing beef steers fed dry-rolled or steam-flaked sorghum grain. J Anim Sci 80(2): 525-532.

13. Archibeque SL, HC Freetly, CL Ferrell (2007) Net portal and hepatic flux of nutrients in growing wethers fed high concentrate diets with oscillating protein concentrations. J Anim Sci 85(4): 997-1005.

14. Wickersham TA, EC Titgemeyer, RC Cochran, EE Wickersham, DP Gnad (2008) Effect of rumen degradable intake protein supplementation on urea kinetics and microbial use of recycled urea in steers consuming low-quality forage. J Anim Sci 86(11): 3079-3088.

15. Rémond D, L Bernard, I Savary Auzeloux, P Noziere (2009) Partitioning of nutrient net fluxes across the portal-drained viscera in sheep fed twice daily: effect of dietary protein degradability. Br J Nutr 102(3): 370-381.

16. Cooper A, plum F (1987) biochemistry and phiysiology of the brain ammonia physiology 67(2): 446519.

17. Tan Z, Murphy MR (2004) Ammonia production, ammonia absorption,and urea recycling in ruminants. Journal of Animal and Feed Sciences 13(3): 389-904.

18. Meijer AJ, Lamers WH, Chamuleau RA (1990) Nitrogen metabolism and ornithine cycle function. Physiol Rev 70(3): 701-748.

19. Alio A, Theurer CB, Lozano O, Huber JT, Swingle RS, et al. (2000) Splanchnic nitrogen metabolism by growing beef steers fed diets containing sorghum grain flaked at different densities. J Anim Sci 78(5) 1355-1363

20. Leng RA, JV Nolan (1984) Nitrogen metabolism in the rumen. J Dairy Sci 67: 1072-1089.

21. Wanapat M (1999) Feeding of ruminants in the tropics based on local feed resources. Khon Kaen Publishing Company Ltd, KhonKaen, Thailand pp. 236

22. Owens FN, Lusby KS, M izwicki K, F Orero O (1980) Slow ammonia release from urea: rumen and metabolism studies. J Anim Sci 50(3): 527-531.

23. Patra AK (2015) Urea/ammonia metabolism in the rumen and toxicity in ruminants. In: Rumen microbiology: from evolution to revolution, Uniya AK, Singh R, Kamra DN (Eds.), New Delhi, Heidelberg, New York, Dordrecht, London, Springer 329-341.

24. Kim M, Morrison M, Yu Z (2011) Status of the phylogenetic diversity census of ruminal microbiomes. FEMS Microbiol Ecol 76(1): 49-63.

25. Firkins J, Yu Z (2006) Characterisation and quantification of the microbial populations in the rumen. In: Ruminant physiology, digestion, metabolism and impact of nutrition on gene expression, immunology and stress. K Sejrsen, T Hvelplund, MO Nielsen (Eds.), Wageningen Academic Publishers, The Netherlands, p. 19-54

26. Lapierre H, Lobley GE (2001) Nitrogen recycling in the ruminant: a review. Journal of Dairy Science 84: 223-236.

27. Abdounk, Stumpff, RabbaniI, Martens H (2010) Modulation of urea transport across sheep rumen epithelium in vitro by SCFA and CO2. Am J Physiol Gastr L 298(2): 190-202.

28. Smith CP, Rousselet G (2001) Facilitative urea transporters. J. Membrane Biol 183: 1-14.

29. Bankir L, Chen K, Yang B (2004) Lack of UT-B in vasa recta and red blood cells prevents urea-induced improvement of urinary concentrating ability. Am J Physiol-Renal 286(1):144-151.
30. Stewart G, Graham C, Cattell S, Smith T, Simmose N, et al. (2005). UT-B is expressed in bovine rumen: potential role in ruminal urea transport. Am J Physiol Reg I 289(2): 605-612.

31. Coyle J, Mcdaids, Walpole C, Stewart GS (2016) UT-B urea transporter localization in the bovine gastrointestinal tract. J Membr Biol 249(1): 77-85.

32. Reynolds CK, GB Huntington (1988) Partition of portal-drained visceral net flux in beef steers. 1 . Blood flow and net flux of oxygen, glucose and nitrogenous compounds across stomach and post-stomach tissues. Br J Nutr 60(3): 539-551

33. Kiran Doranalli (2010) Factors regulating urea-nitrogen recycling in ruminants,a thesis submitted to the college of graduate studies and research in partial fulfillment of the requirements for the degree of doctor of philosophy in the department of animal and poultry science university of saskatche wansaskatoon, skcanada.

34. Koenig KM, Newbold CJ, McIntosh FM, Rode LM (2000) Effects of protozoa on bacterial nitrogen recycling in the rumen.Journal of Animal Science 78(9): 2431-2445.

35. Varady J, Tashenov KT, Boda K, Fejes J, Kosta K (1979) Endogenous urea secretion into the sheep gastrointestinal tract. Physiologia Bohemoslov 28(6): 551-559.

36. Lobley GE, DM Bremner, G Zuur (2000) Effects of diet quality on urea fates in sheep as assessed by refined, non-invasive [15N15N] urea kinetics. Br J Nutr 84(4): 459-468.

37. Gozho GN, MR Hobin, T Mutsvangwa (2008) Interactions between barley grain processing and source of supplemental dietary fat on nitrogen metabolism and urea-nitrogen recycling in dairy cows. J Dairy Sci 91(1): 247-259.

38. Ludden PA, Harmon DL, Huntington GB, Larson BT, Axe DE (2000) Influence of the novel urease inhibitor $\mathrm{N}$-(n-butyl) thiophosphorictriamide on ruminant nitrogen metabolism: II. Ruminal nitrogen metabolism, diet digestibility, and nitrogen balance in lambs. J Anim Sci 78(1):188-198.

39. Norton BW, Murray RM, Entwistle KW, Nolan JV, Ball FM, et al. (1978) The nitrogen metabolism of sheep consuming Flinders grass (Iseilemaspp.), Mitchell grass (Astreblaspp.) and mixed native pasture. Aust J Agr Res 29, 595-603.

40. Engelhardt W, Hinderer S, Wipper E (1978) Factors influencing the endogenous urea-N secretion and utilization in the gastrointestinal tract. In: Osboum DF, Beever DE, Thomson DJ (Eds.), Ruminants Digestion and FeedEvaluation. London: Agricultural Research Council, pp. 4.1-4.12.

41. Remond D, Poncet C and Lefaivre J (1993) Technical note: ruminal vein catheterization and continuous blood flow measurement in ruminal arteries of sheep. Journal of Animal Science 71(5): 1276-1280.

42. Cheng KJ and Wallace RJ (1979) The mechanism of passage of endogenous urea through the rumen wall and the role of ureolytic epithelial bacteria in the urea flow. British Journal of Nutrition 42(3): 553-557.

43. Bailey EA (2010) Effects of supplemental energy and protein on forage digestion andurea kinetics in beef cattle. MS Thesis, Kansas State University, Manhattan 90(10): 3492-34504.

44. Burbank MB, Weaver TJ, Williams BC, Crawford RL (2012) Urease activity of ureolytic bacteria isolated from six soils in which calcite was precipitated by indigenous bacteria. Geomicrobiol J 29: 389-395.

45. Weeks DL, Sachs G (2001) Sites of $\mathrm{p}^{\mathrm{H}}$ regulation of the urea channel of Helicobacter pylori. Mol Microbiol 40(6): 1249-1259.

46. Amlan K, Jörg R (2018) Ureases in the gastrointestinal tracts of ruminant and monogastric animals and their implication in urea-N/ammonia metabolism: A review. Journal of Advanced Research 13: 39-50.

47. Zhao S, Wang J, Zheng N, Bu D, Sun P, Yu Z (2015) Reducing microbial ureolyticactivity in the rumen by immunization against urease therein. BMC Vet Res 11:94. 
48. Harbers LH, Tillman AD, Visek WJ, Glimp HA (1965) Some effects of jackbean urease immunity in young calves. J Anim Sci 24: 102-104.

\section{ISSN: 2574-1241}

DOI: $10.26717 /$ BJSTR.2019.20.003401

Tewodros Alemneh. Biomed J Sci \& Tech Res

(c) Commons Attribution 4.0 License

Submission Link: https://biomedres.us/submit-manuscript.php
49. Parker DS, Lomax MA, seal CJ, Wilton JC (1995) Metabolic implication of ammonia production on in the ruminantes. Proc Nutr Soc 54(2): 549563. 